\title{
Structural and functional responses of harpacticoid copepods to anoxia in the Northern Adriatic: an experimental approach
}

\author{
M. De Troch ${ }^{1}$, M. Roelofs ${ }^{1}$, B. Riedel ${ }^{2}$, and M. Grego ${ }^{3}$ \\ ${ }^{1}$ Ghent University, Biology Department, Marine Biology, Campus Sterre, Krijgslaan 281-S8, 9000 Ghent, Belgium \\ ${ }^{2}$ University of Vienna, Department of Limnology and Oceanography, Althanstrasse 14, 1090 Vienna, Austria \\ ${ }^{3}$ National Institute of Biology, Marine Biology Station of Piran, Fornace 41, SI-6330 Piran, Slovenia
}

Correspondence to: M. De Troch (marleen.detroch@ugent.be)

Received: 21 December 2012 - Published in Biogeosciences Discuss.: 12 February 2013

Revised: 8 May 2013 - Accepted: 28 May 2013 - Published: 26 June 2013

\begin{abstract}
Combined in situ and laboratory studies were conducted to document the effects of anoxia on the structure and functioning of meiobenthic communities, with special focus on harpacticoid copepods. In a first step, anoxia was created artificially by means of an underwater chamber at $24 \mathrm{~m}$ depth in the Northern Adriatic, Gulf of Trieste (Mediterranean). Nematodes were found as the most abundant taxon, followed by harpacticoid copepods. While nematode densities were not affected by treatment (anoxia/normoxia) or sediment depth, these factors had a significant impact on copepod abundances. Harpacticoid copepod family diversity, in contrast, was not affected by anoxic conditions, only by depth. Ectinosomatidae and Cletodidae were most abundant in both normoxic and anoxic samples.

The functional response of harpacticoid copepods to anoxia was studied in a laboratory tracer experiment by adding ${ }^{13} \mathrm{C}$ pre-labelled diatoms to sediment cores in order to test (1) if there is a difference in food uptake by copepods under normoxic and anoxic conditions and (2) whether initial (normoxia) feeding of harpacticoid copepods on diatoms results in a better survival of copepods in subsequent anoxic conditions. Independent of the addition of diatoms, there was a higher survival rate in normoxia than anoxia. The supply of additional food did not result in a higher survival rate of copepods in anoxia, which might be explained by the presence of a nutritionally better food source and/or a lack of starvation before adding the diatoms. However, there was a reduced grazing pressure by copepods on diatoms in anoxic conditions. This resulted in a modified fatty acid composition of the sediment. We concluded that anoxia not only impacts the survival of consumers (direct effect) but also of primary producers (indirect effect), with important implications for the recovery phase.
\end{abstract}

\section{Introduction}

The dissolved oxygen concentration in bottom waters of many shallow coastal seas and estuaries is decreasing, often leading to so-called "dead zones", areas with too little oxygen to support most marine life (Gray et al., 2002; Rabalais et al., 2002). With worldwide more than 400 systems recognized, covering a total area of ca. $245300 \mathrm{~km}^{2}$ (Diaz and Rosenberg, 2008), hypoxia (defined here as DO levels $\leq 2 \mathrm{mLL}^{-1}$ ) and anoxia (no oxygen) are among the top list of emerging environmental challenges (UNEP, 2004; Rabalais et al., 2010) and have been found to expand rapidly (Conley et al., 2011). Hypoxia caused by eutrophication is now considered to be amongst the most pressing water pollution problems in the world (Wu, 2002). Water column stratification - the isolation of bottom water from exchange with oxygen-rich surface water - is another main cause of hypoxia (Diaz, 2001). A comparable phenomenon takes place in the archipelago area of the Baltic Sea, where algal mats become stagnant in shallow embayments, covering wide areas in whose centre hypoxic and even anoxic conditions develop rapidly (Arroyo et al., 2012). The same study showed that the negative impact of hypoxia induced by drifting algal mats (eutrophication) was propagated to almost all levels of the trophic and functional chain, influencing species interactions even at the lowest levels. Moreover, the response to anoxia and the recovery from it can be size- (macrofauna vs. meiofauna) and species-dependent (Wetzel et al., 2002; Arroyo et al., 2006).

In the Northern Adriatic, seasonal oxygen depletions, often associated with massive marine snow events, have also been noted periodically for centuries (Crema et al., 1991). In the second half of the 20th century their frequency and sever- 
ity, however, have markedly increased due to high anthropogenic input of nutrients (Druon et al., 2004). Studies on the effects of hypoxia/anoxia here have mainly focused on benthic macrofauna organisms (i.e. Stefanon and Boldrin, 1982; Stachowitsch, 1984; Occhipinti-Ambrogi et al., 2002). Little research has been done to detect and quantify stress induced by oxygen depletion on meiofauna (Metazoa passing through a $1 \mathrm{~mm}$ sieve but retained on a $38 \mu \mathrm{m}$ sieve) (but see Barmawidjaja et al., 1995; Travizi, 2000). Elmgren (1978) stated that oxygen-dependent zonation of the fauna can occur as macrofauna $(>1 \mathrm{~cm})$ disappears at higher oxygen levels than some of the meiofauna. Especially nematodes are known to persist in low numbers in areas which have been anoxic for long periods. Most information on species- and/or community-level responses (including sensitivity and tolerance) to low DO is mainly provided by aquaculture impact studies (e.g. Grego et al., 2009; Zhou et al., 2012). While aquaculture, however, represents a rather long-term impact (weeks to months) for the benthic fauna, the course of oxygen depletion in the Northern Adriatic often takes place within a few days (Stachowitsch, 1984). The potential short-term impacts (direct and indirect effects) on the meiofauna compartment might be different and are still underdocumented. Besides differences in terms of causes and time frame of anoxia, the ecology and the contribution to ecosystem functioning of the organisms under study are pivotal to evaluate the final impact of anoxia. These parameters will determine the survivors after anoxia and will thus ultimately govern the recovery of the ecosystem. In contrast to several studies on the effects of anoxia on the structural diversity of biotic communities, little is known about their functional response to anoxia, e.g. in terms of their feeding ecology.

The present study focusses on both the structural and functional responses of meiobenthic organisms to hypoxia/anoxia. Because of their small size, high abundances, short generation times and their close association with the sediment, meiobenthic organisms form an appropriate tool to determine the effects of perturbations in aquatic ecosystems (Kennedy and Jacoby, 1999). More specifically, the present study targeted harpacticoid copepods as they represent, after nematodes, the second-most-abundant meiofauna group (Giere, 2009) and are known to respond rapidly to hypoxic/anoxic conditions (Moodley et al., 1997; Modig and Ólafsson 1998). Moreover, harpacticoid copepods form an essential link between primary producers and higher trophic levels (Giere, 2009). Consequently, any impact of low oxygen levels on this group in terms of lower density/diversity will have an important, cascading effect on the energy flow of the overall ecosystem.

To obtain detailed information on shifts in abundance, diversity, community composition and distribution of harpacticoid copepod species after short-term hypoxia/anoxia (i.e. days), an in situ experiment was performed. This field experiment was designed to better understand the impact of anoxia in the Northern Adriatic by gaining detailed infor- mation on the survivors, as this is crucial to interpret postdisturbance community patterns and in the resumption of overall ecosystem functioning. Although copepods have generally been found to be very sensitive to low oxygen levels (e.g. Modig and Ólafsson, 1998; Travizi, 2000), it is important to know which copepod families are most sensitive. Since many hypoxic/anoxic systems are eutrophicationpromoted (Diaz, 2001), the functional response of copepods to additional food supply (using ${ }^{13} \mathrm{C}$ pre-labelled diatoms) was studied in the laboratory. In particular, we tested for differences in diatom uptake by copepods under normoxic and anoxic conditions and whether initial feeding (i.e. before the onset of anoxia) on high-quality food like diatoms resulted in a better survival of and a differential response of the consumers (copepods) to anoxic conditions. The use of trophic tracers, for example, allows testing the effect of additional food sources over the short term (stable isotopes, see review by Boecklen et al., 2011), while fatty acid (FA) profiling (see review by Kelly and Scheibling, 2012) provides insight into changes in the long run. The combination of both techniques will allow measuring carbon assimilation and contribution of provided diatoms to the energy level in the consumers under oxic vs. hypoxic conditions. Here we used FA profiling to check the quality of the food present in the sediment in the control vs. the treatments; subsequently, stable isotope analyses were used to trace the food uptake of copepods in normoxic and anoxic conditions. Data from this experiment will contribute to our knowledge on the energy flow between primary producers and consumers in low-DO conditions, which is a main issue in the overall functioning of benthic communities in impacted sites.

\section{Material and methods}

\subsection{Study area}

The effect of anoxia on meiobenthic organisms, with special focus on harpacticoid copepods, was studied in August 2009 (in situ experiment) and August 2010 (laboratory experiment) in the Gulf of Trieste, Northern Adriatic Sea (Mediterranean). The experimental site is located on a sublitoral soft bottom at $24 \mathrm{~m}$ depth, near the oceanographic buoy of the Marine Biology Station, Piran (Slovenia) about $2 \mathrm{~km}$ offshore $\left(45^{\circ} 32^{\prime} 5.68^{\prime \prime} \mathrm{N}, 13^{\circ} 33^{\prime} 1.89^{\prime \prime} \mathrm{E}\right)$ in order to avoid any impact of fishery activities.

\subsection{In situ experimental set-up and sampling}

Anoxia was experimentally induced in situ from 8 to 12 August 2009 with a plexiglas underwater device $(50 \times 50 \times 50 \mathrm{~cm})$, originally referred to as EAGU (Experimental Anoxia Generating Unit) and described in detail in Stachowitsch et al. (2007). The chamber, originally designed to document macrofauna behaviour during low-DO conditions (see also Riedel et al., 2013), is equipped with 
a digital camera (Canon EOS 30D; images taken in $6 \mathrm{~min}$ intervals), underwater flashes and a sensor array (DO, hydrogen sulphide $\mathrm{H}_{2} \mathrm{~S}$ ). The sensors were positioned $2 \mathrm{~cm}$ above the sediment and values were recorded in 1-min intervals. Bottom water $\mathrm{pH}$ and temperature was measured with a WTW TA $197 \mathrm{pH}$ sensor at the beginning and end of the deployment.

The deployment was terminated on day 5 , and triplicate sediment PVC cores (length $20 \mathrm{~cm}$; inner diameter $=4.6 \mathrm{~cm}$; surface $=16.6 \mathrm{~cm}^{2}$ ) were taken from the anoxic sediment inside the chamber by scuba divers. One day before the end of the deployment (i.e. at day 4) normoxic samples (3 replicates) were taken at ca. 4-5 m distance from the chamber. In the laboratory, the sediment cores were immediately sliced into 5 depth layers: $0-0.5 ; 0.5-1 ; 1-1.5 ; 1.5-2$; and $2-3 \mathrm{~cm}$ and stored in $4 \%$ formaldehyde (final concentration).

Meiobenthic organisms were extracted by washing the sediment on a $1000 \mu \mathrm{m}$ sieve mounted over a $38 \mu \mathrm{m}$ sieve. The sediment retrieved ( $38 \mu \mathrm{m}$ sieve) was centrifuged at $3000 \mathrm{rpm}$ for $10 \mathrm{~min}$ with Ludox solution (specific density of $1.18 \mathrm{~g} \mathrm{~cm}^{-3}$ ) (Heip et al., 1985). This step was repeated 3 times to ensure that all meiofauna was extracted. Finally, meiofauna samples were stained with rose bengal and preserved in $4 \%$ formaldehyde (final concentration).

\subsection{Identification of harpacticoid copepods}

Higher meiofauna taxa were counted under a binocular microscope (cnidarians were not taken into account). Copepods were picked out and stored in $75 \%$ ethanol. For the identification of harpacticoid copepods, all or a minimum of 100 copepods were sorted at random from the extracted samples. From the anoxic and normoxic samples, 3 replicates per layer were identified, yielding a total of about 900 copepods for identification. Picked individuals were mounted on glycerine slides. In order to avoid flattening the specimens and to allow rotation of the animals for better observation, a small piece of a cover glass was placed in the glycerine before closing the slide with a cover glass. Harpacticoid copepods were identified at family level using a Leitz laborlux 12 microscope equipped with a drawing tube. Identification keys included Boxshall and Hasley (2004) and Lang $(1948,1965)$.

\subsection{Laboratory experimental set-up}

To test for the effect of available food (here ${ }^{13} \mathrm{C}$ pre-labelled diatoms) on the response of copepods to anoxia, a lab experiment was set up.

The cores were taken by scuba divers on 3 August 2010 at the same location as the field samples from 2009 (see before). Overall, 24 sediment cores (same dimensions as for field samples) were retrieved and immediately transported to a thermostatic chamber at $17 \pm 1{ }^{\circ} \mathrm{C}$ and stored in complete darkness. The cores were provided with oxygen through an aeration system (tubes connected to the cores) to give a con-

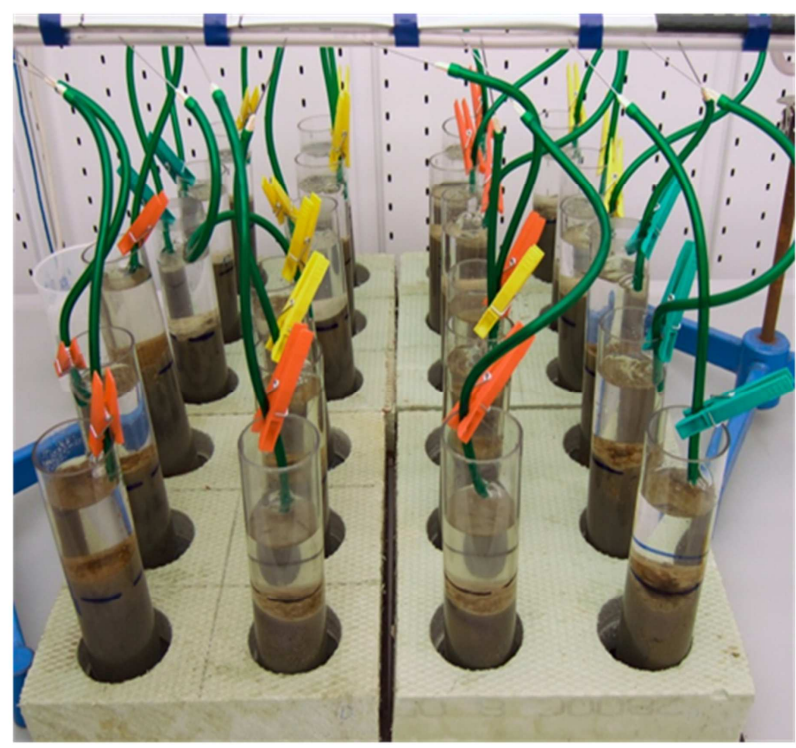

Fig. 1. Experimental set-up of the lab experiment before induction of anoxia $\left(T_{1}\right)$.

stant air flow in the water column. Air tubes were placed in the water column just above the sediment such as not to disrupt the sediment of the cores (Fig. 1). Four additional sediment cores (further referred to as cores taken at $T_{0}$ ) were collected to estimate the field harpacticoid copepod community composition at the start of the experiment.

The effect of feeding before the onset of anoxia was tested using the epipelic pennate diatom Seminavis robusta as additional food source (see also De Troch et al., 2007). The clone involved in the current experimental work is referred to as F2-44 in the diatom culture collection of the Laboratory of Protistology and Aquatic Ecology, Ghent University, Belgium (clones from which the lineage was started were isolated from a sample collected in November 2000 from the "Veerse Meer", a brackish water lake in Zeeland, the Netherlands). By the time of setting the experiment, the diatom cells were $51-56 \mu \mathrm{m}(n=20)$ in length.

To trace the diatom uptake by copepods, the cells were labelled with the stable isotope ${ }^{13} \mathrm{C}$ by adding $5 \mathrm{~mL}$ of a $\mathrm{NaH}^{13} \mathrm{CO}_{3}$ stock solution $\left(336 \mathrm{mg} \mathrm{NaH}{ }^{13} \mathrm{CO}_{3}\right.$ in $100 \mathrm{~mL}$ milliQ $\mathrm{H}_{2} \mathrm{O}$ sodium bicarbonate, ${ }^{13} \mathrm{C}, 99 \%$, Cambridge Isotope Laboratories, Inc.) per $100 \mathrm{~mL} \mathrm{f} / 2$ growth medium (Guillard, 1975).

The diatom cultures were grown in flat tissue bottles $\left(175 \mathrm{~cm}^{2}\right.$ surface) in a climate room at $16-18{ }^{\circ} \mathrm{C}$ with a $12: 12 \mathrm{~h}$ light-dark and $25-50 \mu \mathrm{mol}$ photons $\mathrm{m}^{-2} \mathrm{~s}^{-1}$ light regime. The labelling technique resulted in isotope signatures $\left(\delta^{13} \mathrm{C}\right)$ of $-17.29 \%$ for untreated and $8949.51 \%$ in the ${ }^{13} \mathrm{C}$-enriched cultures. Prior to the experiment, the labelled medium was replaced by autoclaved artificial seawater (salinity: 32 ) without any additional nutrients (no $\mathrm{f} / 2$ growth medium added). 


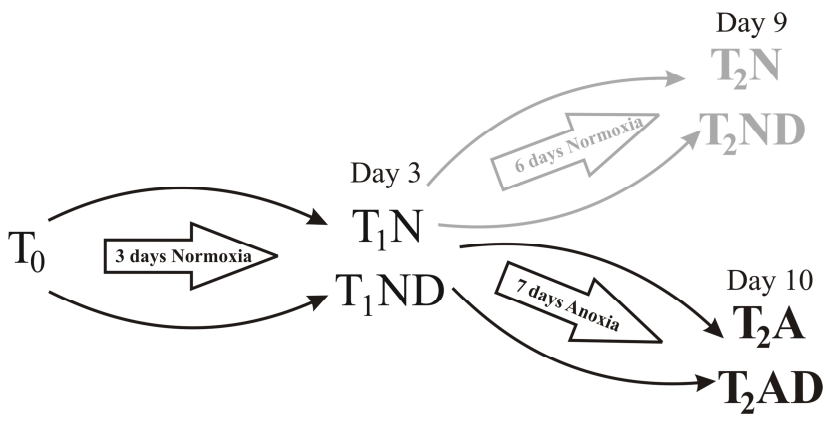

Fig. 2. Experimental design: $T_{0}$ : start of the experiment; $T_{1}: 3$ days; $T_{2}$ : after 6 or 7 days (i.e. 9 or 10 days in total); N: Normoxia; A: Anoxia; D: Diatoms added

To estimate the density of diatom cells in culture, the cells were homogeneously suspended by shaking the bottles in which cultures were grown, and $50 \mu \mathrm{L}$ of the suspension was transferred into a well of a 96-well plate. After cell settlement, their number was counted under a Zeiss Axiovert 40C inverted microscope (Zeiss Gruppe, Jena, Germany), allowing the estimation of the available amount (densities) to apply in the experimental cores. At the start of the experiment (day 1) $1.25 \times 10^{6}$ fresh diatom cells were pipetted into the experimental units, corresponding to about $7.5 \times 10^{5}$ $10 \mathrm{~cm}^{-2}$. The experiment was conducted in complete darkness to avoid additional diatom growth.

\subsection{Experimental design}

The experimental design consisted of 6 treatments with 4 replicates each (Fig. 2):

1. $T_{1} \mathrm{~N}$ : cores incubated for 3 days $\left(T_{1}\right)$ in normoxic conditions (N) (control for $T_{1} \mathrm{ND}$ ).

2. $T_{1} \mathrm{ND}$ : cores incubated for 3 days in normoxic conditions with ${ }^{13} \mathrm{C}$ enriched diatoms (D) $\left(1.25 \times 10^{6}\right.$ cells core $\left.^{-1}\right)$. This treatment allowed checking for difference in copepod abundance between treatments with and without extra diatoms.

3. $T_{2} \mathrm{~N}$ : cores collected at day 9 of the experiment $\left(T_{2}\right)$, i.e. 6 days after $T_{1}$ in normoxic conditions, without extra diatoms. This treatment serves as a control for anoxia without diatoms (treatment $T_{2} \mathrm{~A}$ ).

4. $T_{2} \mathrm{ND}$ : cores in normoxic conditions, enriched with ${ }^{13} \mathrm{C}$ diatoms $\left(1.25 \times 10^{6}\right.$ cells cells core $\left.{ }^{-1}\right)$, collected at day $9\left(T_{2}\right)$ of the experiment, i.e. 6 days after $T_{1}$. This treatment serves as a control for anoxia with diatoms (treatment $T_{2} \mathrm{AD}$ ).

5. $T_{2} \mathrm{~A}$ : cores made anoxic at day $3\left(T_{1}\right)$ of the experiment and collected at day 10, i.e. after 7 days in anoxic conditions $\left(T_{2}\right)$, without extra diatoms. This treatment is a control for anoxic treatment with extra diatoms $\left(T_{2} \mathrm{AD}\right)$.
6. $T_{2} \mathrm{AD}$ : cores enriched with diatoms, made anoxic at day 3 of the experiment and collected at day 10, i.e. after 7 days in anoxic conditions.

Short-term anoxia was created by sealing the core with a thick layer of paraffin oil (density: $0.8 \mathrm{~g} \mathrm{~cm}^{-3}$ ) in order to prevent oxygen diffusion between the seawater and the atmosphere (technique successfully used by Justin and Armstrong, 1983).

The cores were sliced into two layers: $0-1 \mathrm{~cm}$ and $1-3 \mathrm{~cm}$. Meiofauna was extracted by means of decantation with filtered seawater. The sample was put in $5 \mathrm{~L}$ of seawater and stirred, with meiofauna remaining suspended. The supernatant was collected over a $38 \mu \mathrm{m}$ sieve; this was repeated 5 times in order to collect all meiofauna from the sediment (Vincx, 1996). Centrifugation with ludox was not applied as we targeted live copepods for the stable isotope analysis. Furthermore, ludox could impact the final ${ }^{13} \mathrm{C}$ signal through its osmotic effect on components of low molecular weight. The survival rate was estimated by manually removing dead specimens from the sample; live specimens were preserved at $-20^{\circ} \mathrm{C}$ prior to further stable isotope analysis. To detect a reliable ${ }^{13} \mathrm{C} /{ }^{12} \mathrm{C}$ ratios in the tissue of the harpacticoids, a minimum of $15 \mu \mathrm{g} \mathrm{C}$ per sample is required. Therefore we used all live copepods from the $0-1 \mathrm{~cm}$ layer. There was insufficient biomass of copepods in the deeper sediment layer.

\subsection{Stable isotopes, fatty acids and pigment analysis}

Copepods were picked out, washed several times with milliQ water, placed in tin capsules $(8 \times 5 \mathrm{~mm}$, Elemental Microanalysis Limited) within $2 \mathrm{~h}$ (to avoid label leakage) and desiccated overnight at $60^{\circ} \mathrm{C}$. For each replicate, $\delta^{13} \mathrm{C}$ values and copepod biomass (total carbon) were measured with a continuous flow isotope ratio mass spectrometer (type $\mathrm{Eu}-$ ropa Integra) at the UC Davis Stable Isotope Facility (University of California, USA).

Prior to meiofauna extraction, two aliquots of the sediment were taken from each core, one for FA analysis and one for pigment analysis. Hydrolysis of total lipid extracts of sediment (on average $30 \mu \mathrm{g}$ per sample) and methylation to fatty acid methyl esters (FAME) was achieved by a modified onestep derivatization method after Abdulkadir and Tsuchiya (2008). The boron trifluoride-methanol reagent was replaced by a $2.5 \% \mathrm{H}_{2} \mathrm{SO}_{4}$-methanol solution since $\mathrm{BF}_{3}$-methanol can cause artifacts or loss of polyunsaturated fatty acids (PUFA; Eder, 1995). The FA methyl nonadecanoate C19:0 (Fluka 74208) was added as an internal standard to allow quantification. Samples were centrifuged (Eppendorf Centrifuge 5810R) and vacuum dried (Rapid Vap LABCONCO). The FAMEs obtained were analysed using a gas chromatograph (Hewlet Packard 6890N) coupled to a mass spectrometer (HP 5973). All samples were run in splitless mode $\left(1 \mu \mathrm{L}\right.$ injector per run, injector temperature $250^{\circ} \mathrm{C}$ ), using a HP88 column $(60 \mathrm{~m} \times 25 \mathrm{~mm}$ i.d., $\mathrm{Df}=0.20$; Agilent $\mathrm{J} \& \mathrm{~W}$; 
Agilent Co., USA) with a He flow rate of $1.3 \mathrm{~mL} \mathrm{~min}^{-1}$. The initial oven temperature was $50^{\circ} \mathrm{C}$ for $2 \mathrm{~min}$, followed by a ramp at $25^{\circ} \mathrm{C} \mathrm{min}^{-1}$ to $175^{\circ} \mathrm{C}$ and a final ramp at $2{ }^{\circ} \mathrm{C} \mathrm{min}-1$ to $230^{\circ} \mathrm{C}$ with a 4 -min hold. The FAME were identified by comparison with the retention times and mass spectra of authentic standards and mass spectral libraries (WILEY, NITS05), and analysed with the software MSD ChemStation (Agilent Technologies).

Quantification of individual FAME was accomplished by using external standards (SupelcoTM 37 Component FAME Mix, Supelco \# 47885, Sigma-Aldrich Inc., USA). The quantification was obtained by linear regression of the chromatographic peak areas and corresponding known concentrations of the standards (ranging from 5 to $250 \mu \mathrm{g} \mathrm{mL}^{-1}$ ).

Pigments were extracted according to the protocol of Wright and Jeffrey (1997) for chlorophylls and carotenoids of marine phytoplankton. The sediment samples were lyophilized and weighted. Two (2) $\mathrm{mL}$ acetone $90 \%$ was added as extraction fluid, followed by sonication of the samples (30 s in red light) to avoid degradation of pigments. Then $1.5 \mathrm{~mL}$ of the overlying fluid was taken with a syringe containing a filter (Syringe Alltech HPLC 13mm $0.2 \mu \mathrm{m}$ PFTE). The first $0.5 \mathrm{~mL}$ was considered waste, while the last $1 \mathrm{~mL}$ sample was captured in a dark vial immediately closed afterwards. The vials (extract + standards + blank samples) were then placed in the auto sampler of the HPLC (Gilson Macherey-Nagel column C18 250/4.6 nucleodur $5 \mu \mathrm{m}$ ).

\subsection{Data treatment}

\subsubsection{In situ experiment}

Meiofauna counts were standardized to densities $/ 10 \mathrm{~cm}^{2}$. The diversity indices of Hill (1973) were calculated as $N_{0}=$ number of taxa or families; $N_{1}=\exp \left(H^{\prime}\right)$, with $H^{\prime}$ as the Shannon-Wiener diversity index ( $\log _{e}$ based); and $N_{\text {inf }}=$ the reciprocal of the proportional abundance of the most common taxa or family. Community structure was analysed through multidimensional scaling (MDS) based on Bray-Curtis similarity calculations. SIMPER (SIMilarity PERcentage) was carried out, and differences amongst identified groups were tested with a two-way analysis of variance (two-way ANOSIM), with treatment (anoxia/normoxia) and sediment depth as main factors. Calculations and multivariate analyses were performed using the PRIMER 6 software package (version 6.1.10) (Clarke and Warwick, 2001).

\subsubsection{Lab experiment}

Stable isotope ratios are expressed relative to the conventional standards (Vienna Pee Dee Belemnite (VPDB) for carbon) in units of parts per thousand, according to the formula

$\delta X=\left(R_{\text {sample }} / R_{\text {standard }}-1\right) \times 10^{3} \%$,

where $X$ is ${ }^{13} \mathrm{C}$ and $R$ the ratio of ${ }^{13} \mathrm{C} /{ }^{12} \mathrm{C}$.
Incorporation of ${ }^{13} \mathrm{C}$ was expressed as specific uptake, i.e. the difference between the ${ }^{13} \mathrm{C}$ fraction of the control (i.e. based on the natural signature of organisms that did not feed on labelled diatoms) and the sample: $\Delta \delta^{13} \mathrm{C}=\delta^{13} \mathrm{C}_{\text {sample }}-\delta^{13} \mathrm{C}_{\text {control }}$ (where $\delta^{13} \mathrm{C}$ is expressed relative to VPDB standard).

Further standardization of $\delta^{13} \mathrm{C}$ values was done following Middelburg et al. (2000). Incorporation of ${ }^{13} \mathrm{C}$ is reflected as excess (above background) ${ }^{13} \mathrm{C}$ and expressed as total uptake $(I)$ in $\mathrm{mg}^{13} \mathrm{C}$ ind. ${ }^{-1}$, calculated as the product of excess ${ }^{13} \mathrm{C}(E)$ and individual biomass (organic carbon). $E$ is the difference between the fraction ${ }^{13} \mathrm{C}$ of the control $\left(F_{\text {control }}\right)$ and the sample $\left(F_{\text {sample }}\right): E=F_{\text {sample }}-F_{\text {control }}$, where $F={ }^{13} \mathrm{C} /\left({ }^{13} \mathrm{C}+{ }^{12} \mathrm{C}\right)=R /(R+1)$. The carbon isotope ratio $(R)$ was derived from the measured $\delta^{13} \mathrm{C}$ values as $R=\left(\delta^{13} \mathrm{C} / 1000+1\right) \times R_{\mathrm{VPDB}}$ with $R \mathrm{VPDB}=0.0112372$ as $\delta^{13} \mathrm{C}$ is expressed relative to VPDB. This total uptake was further standardized and expressed per unit carbon of copepod.

Differences in uptake were tested by means of twoway analyses of variance (two-way ANOVA) with treatment (anoxia/normoxia) and sediment depth as main factors, using the software Statistica 7.0. Prior to all ANOVAs, Cochran's $C$ test was used to check the assumption of homoscedasticity.

\section{Results}

\subsection{In situ experiment - structural responses}

\subsubsection{Sensor data}

Dissolved oxygen concentration decreased exponentially from initially $5.51 \mathrm{mLL}^{-1}\left(=7.87 \mathrm{mg} \mathrm{L}^{-1}\right)$ to $0 \mathrm{~mL} \mathrm{~L}^{-1}$ within $48 \mathrm{~h}$, and anoxic conditions persisted until the end of the deployment on day $5 . \mathrm{H}_{2} \mathrm{~S}$ started to increase soon after onset of anoxia, from $0 \mu \mathrm{M}$ to final values reaching $\sim 29 \mu \mathrm{M}$. The temperature in the chamber remained constant (average $20^{\circ} \mathrm{C}$ ); the bottom water $\mathrm{pH}$ dropped from initially 8.1 to a minimum of 7.6. The salinity was 38 .

\subsubsection{Meiofauna densities and community composition}

Overall, a two-way ANOVA on the total meiofauna densities (ind $10 \mathrm{~cm}^{-2}$ ) showed a significant effect of sediment depth (decreasing abundance with depth, $p=0.002$ ), while the different oxygen treatments (normoxia/anoxia) interestingly showed no effect $(p=0.05$, Fig. 3a). Nematodes were the dominant meiofauna taxon and reached the highest relative abundance \pm stdev in the $1-1.5 \mathrm{~cm}$ layer in normoxia $(97.8 \pm 3.5 \%)$ and $1.5-2 \mathrm{~cm}$ depth in anoxia $(97.0 \pm 3.7 \%)$. However, no significant effect of treatment (anoxia/normoxia) or depth layer was found ( $p=0.19$ for treatment, $p=0.13$ for depth) for nematodes. Copepods were the second-most-abundant taxon, reaching a maximum relative abundance in the top sediment layers $(0-0.5 \mathrm{~cm}$, 

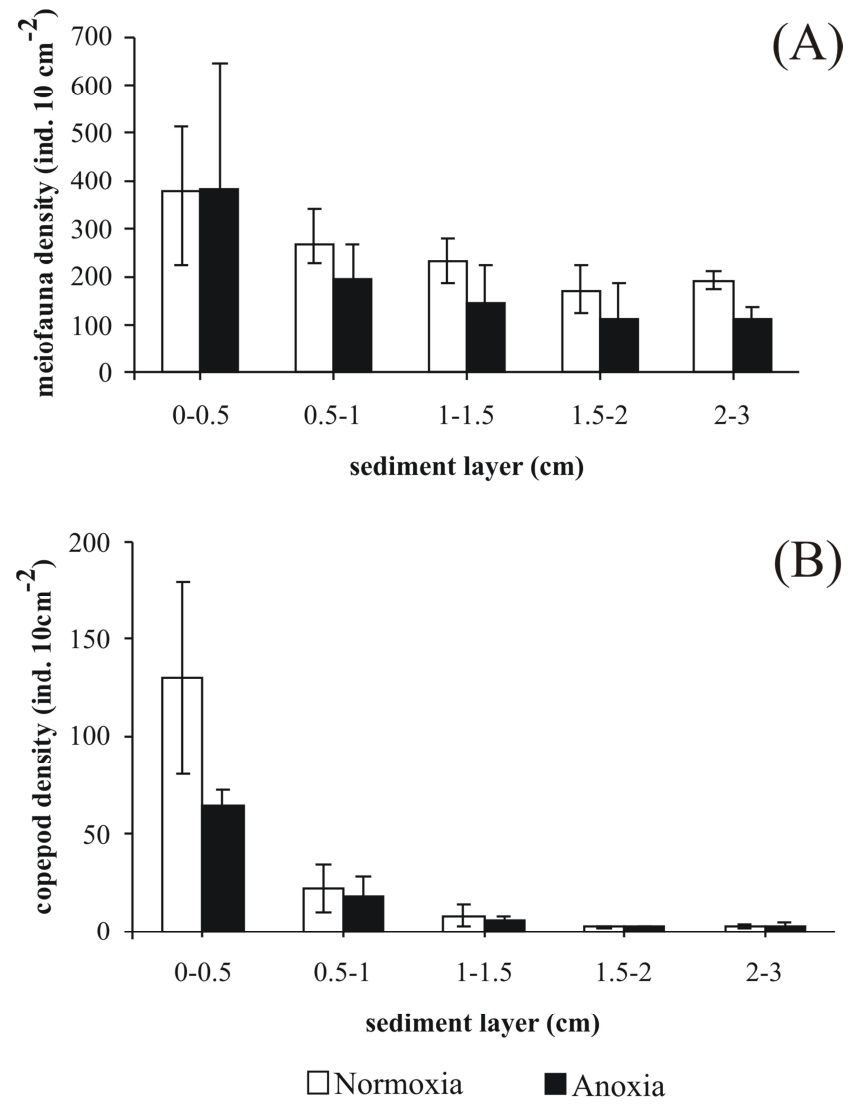

Fig. 3. Average ( \pm stdev) total densities of (A) meiofauna and (B) copepods in normoxic and anoxic field conditions.

normoxia $38.1 \pm 3.1 \%$, anoxia $31.2 \pm 10.6 \%$, respectively). In contrast to nematodes, there was a significant effect of both treatment $(p=0.03)$ and depth $(p<0.001)$ on the relative copepod contribution (Fig. 3b). In the latter case, the difference between normoxia and anoxia was only significant for the top sediment layer $(0-0.5 \mathrm{~cm}$, post hoc Tukey HSD, $p=0.003)$. Kinorhyncha represented the third-mostabundant taxon, with $8.3 \pm 1.3 \%$ at $0.5-1 \mathrm{~cm}$ depth (normoxia) and $12.6 \pm 6.8 \%$ in the top $0-0.5 \mathrm{~cm}$ layer (anoxia). The percentage proportion of Kinorhyncha differed significantly with depth $(p<0.001)$, but there was no effect of treatment $(p=0.84)$.

Remaining taxa present in the normoxic samples included (in order of decreasing abundance) Polychaeta, Ostracoda, Acarina, Bivalvia, Amphipoda, Mysidacea, Turbellaria and Insecta. The anoxic samples contained Polychaeta, Ostracoda, Acarina and Turbellaria. For all these taxa, there was both a treatment $(p=0.04)$ and a sediment depth $(p=0.004)$ effect.

On the MDS plot on the relative meiofauna composition ( stress $=0.05$, Fig. $4 \mathrm{a})$, the top sediment layer $(0-0.5 \mathrm{~cm})$ grouped separately from the deeper layers $(0.5-3 \mathrm{~cm})$, which points to a strong effect of the sediment depth and no clear
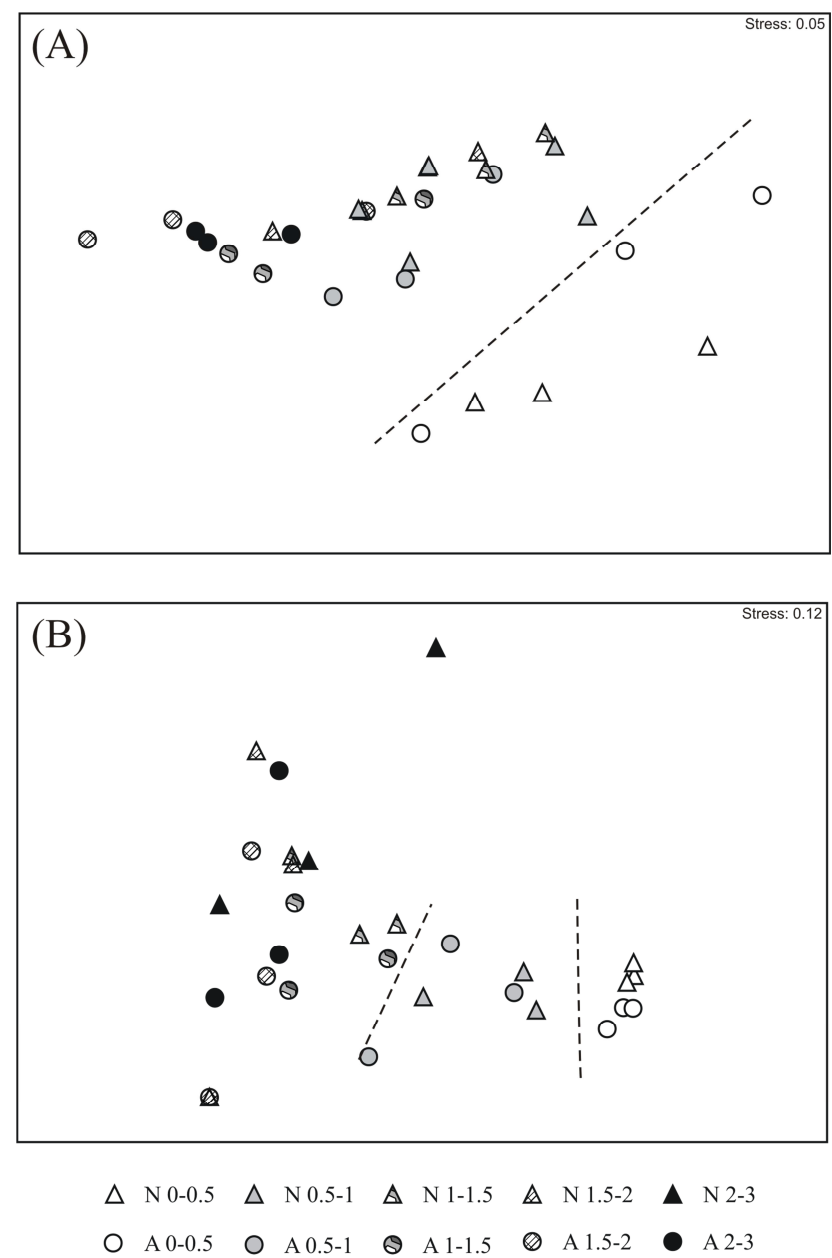

Fig. 4. MDS of relative (A) meiofauna and (B) copepod community composition based on Bray-Curtis similarity: normoxia $(\mathrm{N})$ and anoxia (A), sediment depth layers indicated in $\mathrm{cm}$.

effect of anoxia on relative meiofauna composition. This separation was further confirmed by ANOSIM $(R=0.651$, $p=0.001$ ). A two-way crossed SIMPER analysis showed an average similarity in taxa contribution of $72.4 \%$ in the surface layers $(0-0.5 \mathrm{~cm})$ and $79.8 \%$ in the deeper layers $(0.5-3 \mathrm{~cm})$. Nematodes $(60.0 \%, 95.4 \%$, respectively, in $0-0.5 \mathrm{~cm}$ and $0.5-3 \mathrm{~cm})$ and copepods $(29.5 \%$ in $0-0.5 \mathrm{~cm})$ contributed most to the dissimilarity between surface and the deeper layers.

\subsubsection{Harpacticoid copepod composition}

The relative abundance of the harpacticoid copepod families in normoxic samples (Fig. 5a) showed a dominance of Ectinosomatidae (overall average: $40.1 \pm 23.8 \%$ ) followed by Cletodidae $(28.2 \pm 2.1 \%)$ and Miraciidae $(20.1 \pm 16.9 \%)$. The remaining families accounted for $11.6 \pm 9.2 \%$ of the total relative abundance and included, in order of decreasing abundance, Laophontidae, Longipediidae, Thalestridae, 
(A)

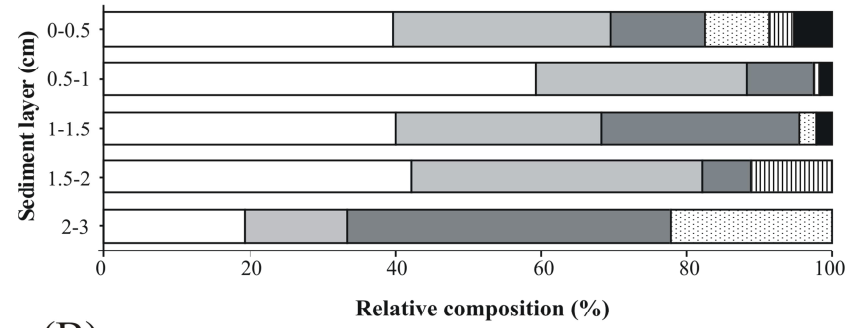

(B)

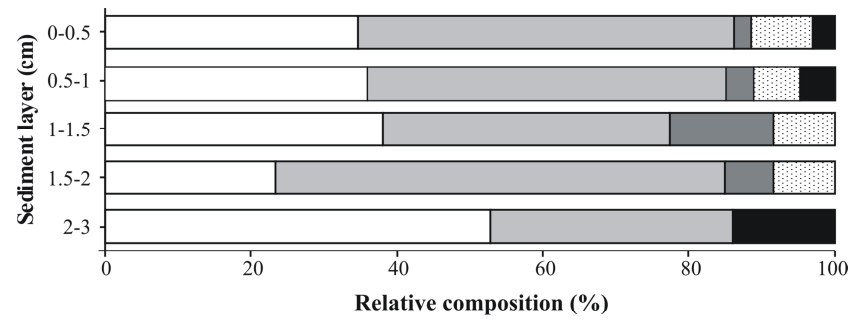

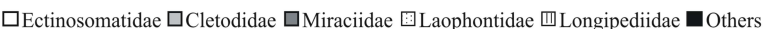

Fig. 5. Relative composition of the harpacticoid copepod families: vertical distribution in (A) normoxic and (B) anoxic conditions.

Tisbidae and Ameiridae. Except for the family Tisbidae $(p=0.06)$, the relative abundance of all families differed significantly with depth (all $p \leq 0.01$ ).

In anoxic samples (Fig. 5b), Cletodidae showed the highest relative abundance $(47.0 \pm 22.4 \%)$ followed by Ectinosomatidae $(37.0 \pm 24.4 \%)$ and Laophontidae $(6.3 \pm 7.9 \%)$. The remaining families $(9.7 \pm 9.6 \%)$ were, in order of decreasing abundance, Miraciidae, Ameiridae, Thalestridae, Longipediidae and Tisbidae. Moreover, Cletodidae represented up to $61.7 \pm 37.5 \%$ and Ectinosomatidae showed a maximum relative contribution of $52.8 \pm 41.1 \%$ (Fig. 5b). Relative abundance differed significantly with sediment depth in Ectinosomatidae $(p<0.01)$, Cletodidae $(p<0.001)$, Thalestridae $(p<0.01)$ and Laophontidae $(p<0.1)$.

The MDS plot (stress $=0.12$, Fig. $4 \mathrm{~b}$ ) of the relative copepod families composition revealed a high similarity between the top layers $(0-0.5 \mathrm{~cm})$ of normoxic and anoxic samples, while the deeper layers showed a higher variability (i.e. sample points are more spread). The difference in relative family composition between surface $(0-0.5,0.5-1 \mathrm{~cm})$ and deeper sediment layers $(1-3 \mathrm{~cm})$ was supported by ANOSIM $(R=0.719, p=0.001)$.

SIMPER analysis showed an average similarity in family composition of $53.2 \%$ in the surface sediment layers $(0-0.5$, $0.5-1 \mathrm{~cm})$ and $46.7 \%$ in the deeper layers $(1-3 \mathrm{~cm})$. Ectinosomatidae $(44.9 \%$ and $41.5 \%$, respectively, in $0-0.5,0.5-$ $1 \mathrm{~cm}$ and $1-3 \mathrm{~cm})$, Cletodidae $(42.4 \%, 42.2 \%)$ and Miraciidae $(6.7 \%, 13.6 \%)$ were the copepod families that contributed most to the dissimilarity between surface and deeper sediment layers.

\subsubsection{Diversity patterns}

Independent of the treatment, the meiofauna in the surface layers $(0-0.5,0.5-1 \mathrm{~cm})$ showed the highest diversity (Table 1a). Overall, the Hill diversity indices (Table 1a) revealed no significant difference in meiofauna diversity between the normoxic and anoxic samples (two-way ANOVA, $p=0.65$ ). However, there is a significant decrease of diversity with increasing sediment depth (two-way ANOVA, $p=0.02$ ), indicated by the number of taxa $\left(N_{0}\right)$ in normoxia and, to a much lesser extent, in anoxia. The decreasing $N_{\text {inf }}$ (Table 1a) values in deeper sediment layers illustrate that the dominance level increased with depth.

For harpacticoid copepods, no significant difference in diversity $\left(N_{0}\right.$, number of families, Table $\left.1 \mathrm{~b}\right)$ was found between normoxic and anoxic samples (two-way ANOVA, $p=0.47)$. Sediment depth, however, had a significant effect, resulting in a decrease in copepod diversity with increasing depth (two-way ANOVA, $p<0.0001$ ).

\subsection{Laboratory experiment - Functional responses}

The initial harpacticoid copepod community at $T_{0}$ was dominated by Cletodidae ( $37.8 \pm 12.1 \%$ ), followed by Laophontidae $(18.3 \pm 2.4 \%)$ and Miraciidae $(17.1 \pm 6.3 \%)$. The remaining families represented $26.8 \pm 4.5 \%$ and included, in order of decreasing abundance, Longipediidae, Ectinosomatidae, Ameiridae, Thalestridae, Tisbidae and Tetragonicipitidae. Copepod family diversity was within the range of the diversity levels recorded for the field experiment (Table 1): $N_{0}=6.8 \pm 1.0 ; N_{\text {inf }}=3 \pm 0.8$; and $H^{\prime}$ $\left(\log _{e}\right)=1.7 \pm 1.0$. The higher $N_{\text {inf }}$ is explained by the lower level of dominance of Cletodidae in comparison to their contribution in the field experiment (collected one year earlier).

The induction of anoxia yielded a significant decrease of the oxygen levels in the overlying water (one-way ANOVA, $p<0.00001)$ from initially $6.6 \pm 0.2 \mathrm{mg} \mathrm{L}^{-1}\left(T_{1} \mathrm{~N}\right)$ and $6.4 \pm 0.06 \mathrm{mg} \mathrm{L}^{-1}\left(T_{2} \mathrm{~N}\right)$ to $0.58 \pm 0.29 \mathrm{mg} \mathrm{L}^{-1}\left(T_{2} \mathrm{~A}\right)$ after 7 days of closure of the core, independent of the addition of extra diatoms or not.

Chlorophyll $a(\mathrm{Chl} a)$ concentrations were measured at time $T_{1}$ and $T_{2}$ and ranged between 0 and $90 \mu \mathrm{g} \mathrm{g}^{-1}$. The addition of diatoms had a highly significant effect on Chl $a$ values $(p<0.0001)$ as samples without additional diatoms had $<5 \mu \mathrm{g} \mathrm{g}^{-1} \mathrm{Chl} a$, while treatments with extra diatoms had $>35 \mu \mathrm{gg}^{-1} \mathrm{Chl} a$. Because of the high variance in $\mathrm{Chl} a$ concentrations in treatments with additional diatoms $\left(83.9 \pm 52.2 \mu \mathrm{gg}^{-1} \quad\left(T_{1} \mathrm{ND}\right), \quad 69.8 \pm 33.3 \mu \mathrm{g} \mathrm{g}^{-1} \quad\left(T_{2} \mathrm{ND}\right)\right.$, $\left.36.6 \pm 24.0 \mu \mathrm{g} \mathrm{g}^{-1}\left(T_{2} \mathrm{AD}\right)\right)$, there was no significant difference in Chl $a$ between the different time intervals, $T_{1}$ and $T_{2}$, (one-way ANOVA, $p=0.35$ ). Another pigment, Chlorophyll $c 2$ (Chl $c 2$ ), showed similar patterns to $\mathrm{Chl} a$ with maximum $3.5 \pm 4.2 \mu \mathrm{g} \mathrm{g}^{-1}\left(T_{1} \mathrm{~N}\right)$ in treatments without diatoms and up to $8.7 \pm 7.2 \mu \mathrm{g} \mathrm{g}^{-1}$ after adding diatoms ( $T_{2} \mathrm{ND}$ ). In terms of carotenoids, the concentration of fucoxanthin ranged 
Table 1. Average Hill's diversity indices $( \pm$ stdev) for $(\mathrm{A})$ meiofauna taxa and (B) copepod family composition in the field experiment. $N_{0}=$ number of taxa; $N_{\text {inf }}=$ dominance index; $H^{\prime}\left(\log _{e}\right)=\Sigma P_{i}^{2} \log \left(P_{i}\right) ; \mathrm{N}=$ Normoxia; A = Anoxia; sediment depth layers indicated in $\mathrm{cm}$. Averaged values ( \pm stdev) over all depth layers.

\begin{tabular}{lccc|ccc}
\hline (A) & \multicolumn{7}{c}{$N^{\prime}$} \\
\hline Depth $(\mathrm{cm})$ & $\mathrm{N}_{0}$ & $N_{\text {inf }}$ & $H^{\prime}\left(\log _{e}\right)$ & $N_{0}$ & $N_{\text {inf }}$ & $H^{\prime}\left(\log _{e}\right)$ \\
\cline { 2 - 7 } & \multicolumn{5}{c|}{ Normoxia } & \multicolumn{3}{c}{ Anoxia } \\
\hline $0-0.5$ & $6.3 \pm 0.6$ & $1.9 \pm 0.1$ & $1.1 \pm 0.1$ & $5.3 \pm 1.0$ & $1.6 \pm 0.4$ & $0.9 \pm 0.3$ \\
$0.5-1$ & $4.3 \pm 1.5$ & $1.2 \pm 0.1$ & $0.5 \pm 0.3$ & $4.3 \pm 0.6$ & $1.2 \pm 0.1$ & $0.5 \pm 0.2$ \\
$1-1.5$ & $4.0 \pm 0.0$ & $1.1 \pm 0.0$ & $0.2 \pm 0.3$ & $5.0 \pm 0.0$ & $1.1 \pm 0.0$ & $0.4 \pm 0.0$ \\
$1.5-2$ & $3.7 \pm 0.6$ & $1.0 \pm 0.0$ & $0.2 \pm 0.0$ & $4.3 \pm 0.6$ & $1.0 \pm 0.0$ & $0.2 \pm 0.2$ \\
$2-3$ & $4.3 \pm 0.6$ & $1.0 \pm 0.0$ & $0.2 \pm 0.0$ & $4.7 \pm 1.2$ & $1.1 \pm 0.0$ & $0.2 \pm 0.1$ \\
\hline overall & $4.5 \pm 1.2$ & $1.2 \pm 0.4$ & $0.4 \pm 0.3$ & $4.7 \pm 0.7$ & $1.2 \pm 0.2$ & $0.4 \pm 0.2$ \\
\hline
\end{tabular}

(B)

\begin{tabular}{cccc|ccc}
\hline Depth (cm) & $\mathrm{N}_{0}$ & $N_{\text {inf }}$ & $H^{\prime}\left(\log _{e}\right)$ & $N_{0}$ & $N_{\text {inf }}$ & $H^{\prime}\left(\log _{e}\right)$ \\
\cline { 2 - 6 } & \multicolumn{3}{c}{ Normoxia } & \multicolumn{3}{c}{ Anoxia } \\
\hline $0-0.5$ & $7.7 \pm 0.6$ & $2.6 \pm 0.5$ & $1.5 \pm 0.1$ & $6.0 \pm 0.0$ & $2.0 \pm 0.2$ & $1.1 \pm 0.1$ \\
$0.5-1$ & $3.7 \pm 1.5$ & $1.6 \pm 0.4$ & $0.9 \pm 0.4$ & $4.3 \pm 0.6$ & $1.8 \pm 0.4$ & $1.0 \pm 0.1$ \\
$1-1.5$ & $3.7 \pm 1.2$ & $2.2 \pm 0.5$ & $1.1 \pm 0.2$ & $3.0 \pm 0.0$ & $2.1 \pm 0.2$ & $1.0 \pm 0.1$ \\
$1.5-2$ & $2.0 \pm 1.0$ & $1.4 \pm 0.4$ & $0.5 \pm 0.5$ & $2.3 \pm 1.2$ & $1.6 \pm 0.5$ & $0.7 \pm 0.6$ \\
$2-3$ & $3.0 \pm 1.0$ & $2.3 \pm 0.6$ & $1.0 \pm 0.3$ & $2.3 \pm 1.2$ & $1.7 \pm 0.6$ & $0.7 \pm 0.6$ \\
\hline overall & $4.0 \pm 2.2$ & $2.0 \pm 0.6$ & $1.0 \pm 0.4$ & $3.6 \pm 1.6$ & $1.8 \pm 0.4$ & $0.9 \pm 0.4$ \\
\hline
\end{tabular}

between $1.3 \pm 0.1 \mu \mathrm{g} \mathrm{g}^{-1}$ and $2.0 \pm 0.4 \mu \mathrm{g} \mathrm{g}^{-1}$ without additional diatoms and between $18.2 \pm 19.2 \mu \mathrm{g} \mathrm{g}^{-1}\left(T_{2} \mathrm{AD}\right)$ and $39.7 \pm 24.8 \mu \mathrm{g} \mathrm{g}^{-1}\left(T_{2} \mathrm{ND}\right)$ in treatments with extra diatoms.

\subsubsection{Survival rate}

The survival rate of harpacticoid copepods was significantly higher in normoxic conditions $(93.2 \pm 3.7 \%)$ than in anoxic conditions $(73.6 \pm 16.2 \%)$ at $T_{2}$ (two-way ANOVA, $p=0.005$ ). Additional food supply tended to have a negative effect on copepod survival as the average survival rate for treatments with extra diatoms was $79.9 \pm 14.5 \%$ in contrast to $86.9 \pm 16.1 \%$ in treatments without extra diatoms. Due to the high variance, this effect was, however, not significant (two-way ANOVA, $p=0.2$ ). More specifically, the anoxic treatment with extra diatoms $\left(T_{2} \mathrm{AD}\right)$ had a lower survival rate $(66.9 \pm 5.8 \%)$ than the one without extra diatoms $\left(80.3 \pm 21.5 \%, T_{2} \mathrm{~A}\right)$. In combination with the effect of the anoxic condition, the former $\left(T_{2} \mathrm{AD}\right)$ had a significantly lower survival rate than the oxic treatments with or without extra diatoms ( $T_{2} \mathrm{ND}: 93.0 \pm 2.0 \% ; T_{2} \mathrm{~N}$ : $\left.93.5 \pm 5.3 \%\right)$ (post hoc Tukey HSD, $p<0.01$ ). It is worth noting that there was no effect of food addition on the survival rate in the oxic treatments $\left(T_{2} \mathrm{~N}, T_{2} \mathrm{ND}\right)$.

\subsubsection{Diatom uptake as indicated by biomarkers}

The total FA concentration in the sediment was highest in treatments with additional diatoms (note different scales in Fig. 6a, b), with the highest values in $T_{1} \mathrm{ND} \quad\left(307.6 \pm 42.0 \mu \mathrm{g} \mathrm{mL}^{-1}\right)$ and $T_{2} \mathrm{AD}$ $\left(966.1 \pm 272.2 \mu \mathrm{g} \mathrm{mL}^{-1}\right)$. The unsaturated FA C16: $1 \omega 7$, for example, was most abundant in these treatments, and linoleic acid C18:2 $2 \omega 6$ was found only in samples with additional diatoms. Independent of the additional food supply, the anoxic samples showed a higher total FA concentration than the normoxic treatments (Fig. 6a, b). Especially the relative contribution of $\mathrm{C} 16: 1 \omega 7$ increased in the anoxic conditions, in particular when diatoms were added $\left(T_{2} \mathrm{~A}, T_{2} \mathrm{AD}\right.$, Fig. $6 \mathrm{c}$, d).

Before the onset of the anoxia, the copepods were fed for 3 days with labelled diatoms, which resulted in the increase of their $\delta^{13} \mathrm{C} \pm \operatorname{stdev}$ from $-22.4 \pm 1.4 \%$ o $\left(T_{1} \mathrm{~N}\right)$ to $276.9 \pm 192.8 \%$ o $\left(T_{1} \mathrm{ND}\right)\left(\Delta \delta^{13} \mathrm{C}=299.2 \pm 192.8 \%\right.$ o $)$. In the normoxic treatments, a significant increase of $\Delta \delta^{13} \mathrm{C}$ from $T_{1} \mathrm{ND}\left(299.2 \pm 192.8 \%\right.$ ) to $T_{2} \mathrm{ND}(1281.5 \pm 667.6 \%$ ) was recorded (one-way ANOVA, $p=0.03$ ), indicating continuous feeding in normoxia (Fig. 7). In the anoxic treatments, food uptake ceased, with $\Delta \delta^{13} \mathrm{C}$ values showing no significant difference between $T_{1}$ ND $(299.2 \pm 192.8 \%$ o $)$ and $T_{2} \mathrm{AD}(138.6 \pm 43.0 \%$ ) (one-way ANOVA, $p=0.16)$. Consequently, the $\Delta \delta^{13} \mathrm{C}$ value differed significantly 

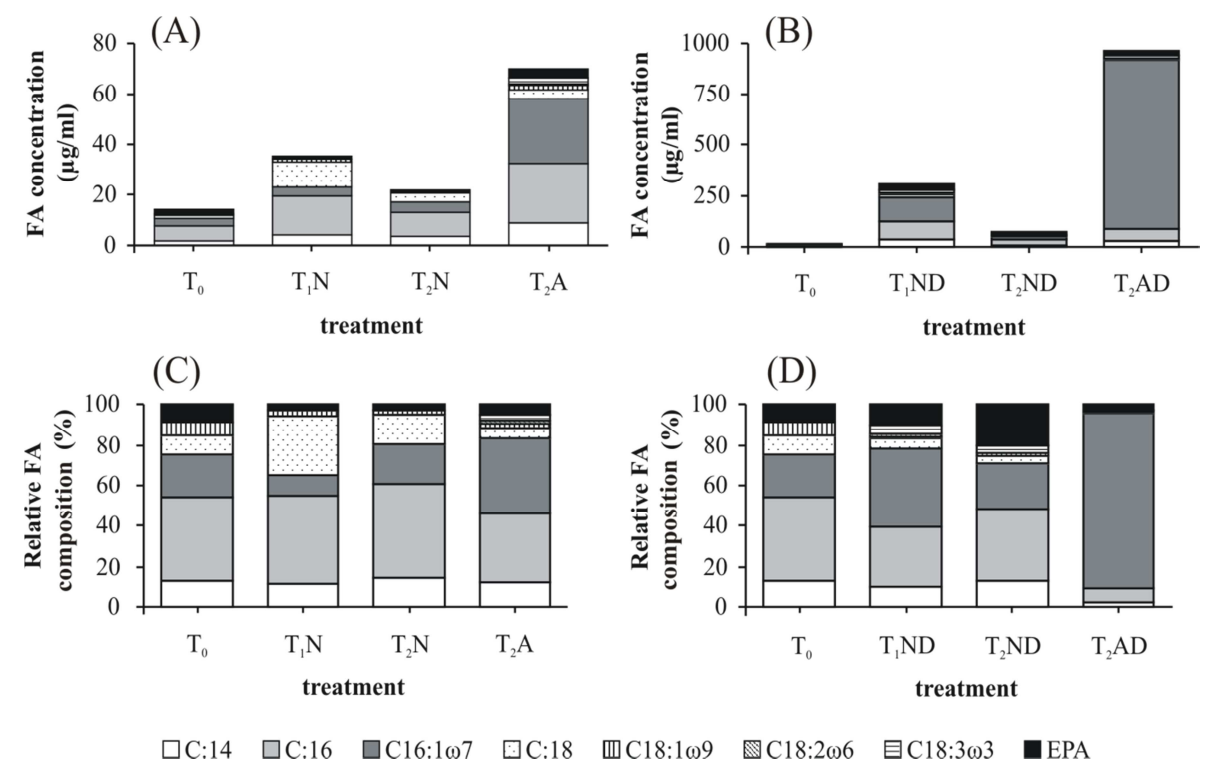

Fig. 6. Absolute and relative fatty acid composition of the sediment $(0-3 \mathrm{~cm})$ for treatments without extra diatoms (A, C) and for treatments with diatoms $(\mathbf{B}, \mathbf{D})$.

between normoxic and anoxic treatment (one-way ANOVA, $p=0.014)$.

\section{Discussion}

\subsection{In situ experiment}

In the present field experiment, total meiofauna densities were not significantly affected by anoxic conditions. This is in contrast with previous studies that showed a significant decrease of meiofauna densities due to anoxia (Moodley at al., 1997; Travizi, 2000). While studies on macrofauna revealed a peak in mortality at the transition from severe hypoxia to anoxia (Riedel et al., 2012), meiofauna - in general being more tolerant (Moodley et al., 1997) - decreased in density, but some may still be alive. Van Colen et al. (2009) created hypoxic conditions in a tidal mudflat for 40 days. While no macrobenthos survived, nematode diversity and abundances, for example, changed, but no complete mortality occurred. The strong resistance of nematodes to anoxia and the fact that they are the dominant meiofauna group can explain the lack of a clear effect of anoxia on total meiofauna density.

Another and probably reliable explanation is the short duration of the anoxic/sulphidic phase (i.e. 5 days). In contrast to long-term impact studies, e.g. from aquaculture impact (see Grego et al., 2009), the present study aimed to analyse short-term effects since this is often the case in the Northern Adriatic (Stachowitsch, 1984). The present study concluded that only copepods showed a short-term anoxia response, while nematodes, kinorhynchs and other meiofauna taxa were not affected. In addition to the duration of anoxia,

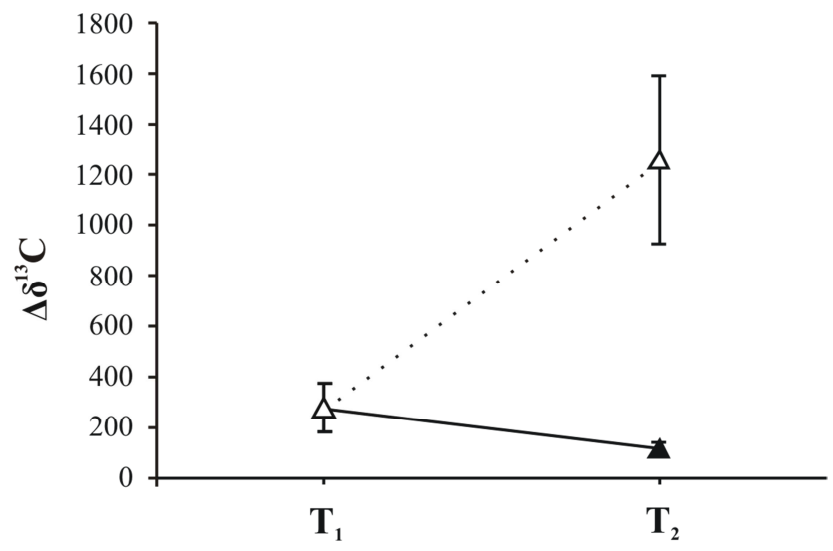

Time interval

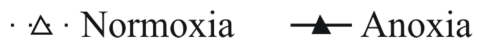

Fig. 7. Average ( \pm STDEV) diatom uptake by harpacticoid copepods under normoxic and anoxic conditions at two time intervals $\left(T_{1}, T_{2}\right)$ expressed as specific uptake $\left(\Delta \delta^{13} \mathrm{C}\right) . T_{2}$ represents 6 or 7 additional days in normoxic or anoxic conditions, respectively.

also the way of creating anoxia can be pivotal in the interpretation of the results. The way the benthic underwater chamber created anoxia could also explain the lack of response by meiofauna. By sealing a $50 \mathrm{~cm} \times 50 \mathrm{~cm} \times 50 \mathrm{~cm}$ volume off from the surrounding environment (Stachowitsch et al., 2007), the field experiment mimics the situation where water column stratification is the main cause of hypoxia, i.e. the isolation of bottom water from oxygen-rich surface water (Diaz, 2001). As this set-up caused a total cut-off from the 
food supply, eutrophication as an important factor in creating anoxia (Gray et al., 2002) was however neglected. In view of their large biomass and energy storage, macrofauna can generally cope with low- to no-food supply for longer periods (Ott, 1981). Moreover, a 5-day experiment/cut-off is negligible compared to weeks of strong stratification. The response of meiofauna is less well known, and we can merely speculate that their low energy demands may be crucial to overcome food restrictions. In that context, the lab experiment (see further) could contribute to our understanding of the role of food for the response of meiofauna to anoxia because it tested specifically for the effect of food level (normal or elevated).

In contrast to the lack of a clear effect of anoxia on meiofauna, it was mainly the sediment depth that determined meiofauna densities and community composition. This corresponds with other meiofauna studies where the upper few centimetres of the sediment harboured more meiofauna than the deeper horizons (see review by Giere, 2009). As there was no significant difference in overall density between the natural (normoxic) and the treated cores (anoxia), we conclude that the impacted meiofauna community corresponded to a "natural, pristine" meiofauna community. Note that the meiofauna counts for this study were based on rose-bengalcoloured individuals and may therefore be an overestimation of the actual number of life animals (see Grego et al., 2013a).

Nematodes are known to dominate in terms of abundance and biomass in most meiofauna samples (Giere, 2009) and were also the most abundant taxon in this study, independent of the treatment (normoxia and anoxia), followed by copepods. Our results showed that nematode densities were not affected by depth and treatment, whereas copepods were less abundant in anoxic conditions and in the deeper sediment layers. This difference in response can be due to phylogenetic constraints and lifestyle (Wetzel et al., 2001). Typically, a low oxygen demand in combination with a high surface: volume ratio enable some species to survive hypoxia/anoxia for extended times.

Studies within a given habitat typically concluded that of all permanent meiobenthic taxa, foraminiferans (see also Langlet et al., 2013) and nematodes are best adapted to hypoxia/anoxia and that crustaceans (e.g. copepods) are the least tolerant (see review by Wetzel et al., 2001). The generally high tolerance of nematodes to low oxygen concentrations (see also Moodley et al., 2000) often results in an increase in their relative abundance. One of the mechanisms to escape from temporal anoxia is to migrate from hypoxic sediments into the water column and to settle again to the sediment with the return of normoxic conditions (Wetzel et al., 2001). Harpacticoid copepods, in contrast, represent the meiobenthic taxon most sensitive to low DO levels (Hicks and Coull, 1983; Modig and Ólafsson 1998; Travizi, 2000), which might explain their restriction to the well-oxygenated top sediment layers.
A similar trend was found for meiofauna diversity: it decreased with depth, independent of the treatment (anoxia vs. normoxia). The top sediment layers $(0-0.5,0.5-1 \mathrm{~cm})$ were also characterized by the highest meiofauna taxa diversity.

At lower taxonomic level, there was a clear effect of anoxia on the harpacticoid copepods' family composition. The families Ectinosomatidae and Cletodidae dominated in anoxic conditions, while the abundance of other families, including Longipediidae and Miraciidae, decreased rapidly in anoxic conditions. Very little is known so far about differential resistance of harpacticoid copepod families to anoxia (but see Grego et al., 2013b). Overall, harpacticoid copepods have a high sensitivity to low-oxygen conditions (see before), except for so-called worm-like copepod species belonging to the families Paramesochridae and Leptastacidae, thought to be able to survive in anoxic conditions (Hicks and Coull, 1983). The diversity of harpacticoid copepod families differed significantly with depth. Again, as for meiofauna taxa, depth was found to be the most important factor structuring the harpacticoid copepod community.

\subsection{Lab experiment}

The lab experiment was conducted to get a better insight into the functional responses of harpacticoid copepods to anoxia. The initial copepod community (at $T_{0}$ ) differed slightly from the one reported for the field experiment (see before, collected one year earlier). The community was dominated by the families Cletodidae, Laophontidae and Miraciidae, but a lower share of Ectinosomatidae was found, while they dominated in the normoxic cores of the field experiment. This can be explained by interannual variability in the benthic communities. However, the samples collected the year afterwards by Grego et al. (2013b) were also dominated by the family Cletodidae. Cletodidae were also found to dominate in the anoxic cores of the field experiment in the present study. Next to interannual variability, the underestimation of the family Ectinosomatidae can also be due to the extraction via decantation and not by means of centrifugation with Ludox (see field experiment). Since we wanted to use the live copepods, i.e. the individuals that survived the lab experimental treatment, the use of Ludox was not an option. Species of the family Ectinosomatidae are often rather small and closely associated with sediment grains, it is plausible that they were not sufficiently extracted by the decantation method. In spite of these small differences in copepod family composition, there were no major changes in the overall diversity as the average number of copepod families in the $T_{0}$ cores $(6.8 \pm 1.0)$ falls within the ranges reported for the normoxic $(7.7 \pm 0.6)$ and anoxic cores $(6.0 \pm 0.0)$ of the field experiment.

The use of pre-labelled diatoms (i.e. Seminavis robusta), as a typical food source for many meiofaunal taxa (Giere, 2009), proved to be successful in previous studies on harpacticoid copepods and their contribution to the energy flow in benthic ecosystems (e.g. De Troch et al., 2006, 2007). 
The attractiveness of meiofauna to diatoms can mainly be explained by the high content of PUFA and the FA C16:1 $1 \omega 7$ (De Troch et al., 2012). First we wanted to test for a functional response in terms of food uptake by harpacticoid copepods in anoxic conditions. Previous studies indicated that anoxia negatively affected feeding behaviour of planktonic calanoid copepods Acartia tonsa (Sedlacek and Marcus, 2005) and of the juvenile blue crabs Callinectes spp. (Das and Stickle, 1993). Widdows et al. (1989), for example, explained the reduced food uptake by oyster larvae (Crassostrea virginica) in anoxia as a way to save energy because digestion and absorption of food accounted for about $17 \%$ of total metabolic energy expenditure. Studies on harpacticoid copepods showed that organisms became quiescent in order to survive unstable niches (Vopel et al., 1996). The same was observed for planktonic copepods, which entered a form of stasis, shutting down metabolic activity to minimize the energy expense of respiration (Kiørboe et al., 1985). This could explain why the copepods survived low-DO conditions but showed no feeding in the anoxic treatments. They even leaked some of the heavy carbon $\left({ }^{13} \mathrm{C}\right)$ into the environment.

As expected, copepods in normoxic conditions had a 1.25times-higher survival rate than copepods in anoxic conditions. Furthermore, we hypothesized that an additional highquality food source before the start of anoxic conditions might result in a higher survival rate during anoxia. Diet and level of food intake influence oxidative stress (Monaghan et al., 2009), and dietary intake influences the availability of exogenous antioxidants. Reduced caloric intake is known to be associated with reduced oxidative damage (Masoro, 2006). Souza et al. (2010), for example, found that certain calanoid copepods species survived better when they received additional food at the onset of a stress condition (i.e. ultravioletradiation-induced oxidative stress). In contrast, in our experiment additional food did not yield any higher survival rate in anoxic conditions. One explanation might be the different types of stress involved in a mesocosm. However, also Sedlacek and Marcus (2005) found that the reduced egg production of the calanoid copepod Acartia tonsa as a response to anoxia could not be mitigated by extra food (dinoflagellates).

Another explanation is that we did not reach complete anoxia in the sediment cores in the laboratory (DO was measured in the overlying water), although low oxygen concentrations in the water column can lead to anoxic conditions in the sediments (Diaz, 2001). Alternatively, as decomposition of organic matter (here diatoms) typically results in low oxygen concentrations (Gray et al., 2002), the cores with additional diatoms $\left(T_{2} \mathrm{AD}\right)$ were expected to have lower $\mathrm{DO}$ concentrations and consequently lower survival rates than those without diatoms. This was, however, not the case in the present study as there was no significant difference in oxygen level in cores with or without extra diatoms. In both cases the oxygen level was as low as $0.58 \pm 0.29 \mathrm{mg} \mathrm{L}^{-1}$ $\left(=0.41 \pm 0.20 \mathrm{mLL}^{-1}\right)$. This oxygen level can be ranked as medium severe hypoxia because it is just $\leq 0.5 \mathrm{mLL}^{-1}$
(Riedel, unpublished data), whereas in the field experiment it dropped down to $0 \mathrm{~mL} \mathrm{~L}^{-1}$.

Finally, it is possible that there was already a high amount of initial food present in the sediment and any addition of extra diatoms would not imply any significant difference between both treatments at the onset of anoxia. The contrary, however, was true because the Chl $a$ concentrations increased significantly in the treatments with additional diatoms. Moreover, the FA composition of the sediments without additional diatoms did not show the presence of any other good food source, as FA concentrations in these cores were relatively low. The increase of the FA $16: 1 \omega 7$, which is typical for diatoms, in the treatment with extra diatoms underlined this. More interestingly, however, was the considerable increase of FA in anoxic conditions, independent of the treatment (additional diatoms or not). This can be explained by a reduced grazing pressure by copepods on diatoms in anoxic conditions. Thus, anoxia does not only impact the survival of consumers (direct effect) but also of primary producers (indirect effect). Moreover, the reduced grazing pressure and the increased diatom density might have important consequences for the recovery phase after anoxia. Van Colen et al. (2012) stressed that a full recovery of ecosystem functioning after hypoxia implies a complete recovery of organismsediment interactions. The latter mainly points to bioturbating (macro)organisms. Nonetheless, the present study underlines the role of the players at the basis of the food web, i.e. the primary producers and grazers on them, as being essential for the recovery phase.

\section{Conclusions}

In contrast with what we expected, total meiofauna community density was not affected by anoxic conditions, mainly because of the dominance of highly tolerant nematodes. Sediment depth seemed to be the most important factor structuring meiofauna communities in our in situ experiment. The lack of effect of anoxia on total meiofauna composition could be due to too-short incubation time of the benthic underwater chamber for the effect to be shown on the most abundant meiofauna group, the nematodes. Deployments for longer time intervals (i.e. 1 month, 2 months, $1 \mathrm{yr}$ ) have been done but focused on foraminiferans (Langlet et al., this volume) and sediment geochemistry (Koron et al., this volume; Metzger et al., this volume). Moreover, novel approaches, such as the use of vital stains, may allow a more accurate assessment of alive/dead individuals following short-term impact by hypoxia and anoxia (e.g. see Grego et al., 2013a, for copepods and nematodes). Harpacticoid copepods were the most sensitive meiofauna taxa to low oxygen concentrations. While densities of harpacticoid copepods were impacted by both sediment depth and anoxia, family diversity was affected by depth only. Stable isotope analysis showed that initial feeding with diatoms did not result in a higher survival rate under 
anoxic conditions. In fact, copepods stopped feeding under anoxic conditions, yielding increased primary producer levels. Accordingly, this reduced grazing response has important implications for the recovery phase.

Acknowledgements. The research was conducted in the framework of the Austrian Science Fund (FWF) project P21542-B17 entitled "Low dissolved oxygen events in the Northern Adriatic: in situ experimental insights into benthic responses before, during and post-anoxia". Additional financial support was received from the Marine Biology Section at Ghent University. The first author is a postdoctoral researcher at Ghent University (BOF-GOA 01GA1911W). Special thanks to Ir. Dirk Van Gansbeke (Marine Biology, UGent) for the fatty acid analyses. We thank M. Stachowitsch, M. Zuschin, I. Gallmetzer and A. Haselmair for technical and diving support. Special thanks go to the director and staff of the Marine Biology Station (MBS) in Piran, Slovenia, for their hospitality and support during our work. The authors wish to thank the three referees for their valuable remarks that helped us to improve an earlier version of the manuscript.

Edited by: H. Rumohr

\section{References}

Abdulkadir, S. and Tsuchiya, M.: One-step method for quantitative and qualitative analysis of fatty acids in marine animal samples, J. Exp. Mar. Biol. Ecol., 354, 1-8, 2008.

Arroyo, N. L., Aarnio, K., and Bonsdorff, E.: Drifting Algae as a means of Re-Colonizing Defaunated Sediments in the Baltic Sea. A Short-Term Microcosm Study, Hydrobiologia, 554, 8395, 2006.

Arroyo, N. L., Aarnio, K., Mäensivu, M., and Bonsdorff, E.: Drifting filamentous algal mats disturb sediment fauna: Impacts on macro-meiofaunal interactions, J. Exp. Mar. Biol. Ecol., 420421, 77-90, 2012.

Barmawidjaja, D. M., Van Der Zwaan, G. J., Jorissen, F. J., and Puskaric, S.: 150 years of eutrophication in the northern Adriatic Sea, evidence from a benthic foraminiferal record, Mar. Geol., 122, 367-384, 1995.

Boecklen, W. J., Yarnes, C. T., Cook, B. A., and James, A. C.: On the use of stable isotopes in trophic ecology, Annu. Rev. Ecol. Evol. S., 42, 411-440, 2011.

Boxshall, G. and Hasley, S. H. (Eds): An Introduction to Copepod Diversity. Ray Society, London, 966 pp., 2004.

Clarke, K. R. and Warwick, R. M.: Changes in marine communities: an approach to statistical analysis and interpretation, 2nd Edn., PRIMER-E: Plymouth, 172 pp., 2001.

Conley, D. J., Carstensen, J., Aigars, J., Axe, P., Bonsdorff, E., Eremina, T., Haahti, B. M., Humborg, C., Jonsson, P., Kotta, J., Lannegren, C., Larsson, U., Maximov, A., Medina, M. R., Lysiak-Pastuszak, E., Remeikaite-Nikiene, N., Walve, J., Wilhelms, S., and Zillen, L.: Hypoxia is increasing in the coastal zone of the Baltic Sea, Environ. Sci. Technol., 45, 677-6793, 2011.

Crema, R., Castelli, A., and Prevedelli, D.: Long term eutrophication effects on macrofaunal communities in Northern Adriatic Sea, Mar. Pollut. Bull., 22, 503-508, 1991.
Das, T. and Stickle, W. B.: Sensitivity of crabs Callinectes sapidus and $C$. similis and the gastropod Stramonita haemastoma to hypoxia and anoxia, Mar. Ecol.-Prog. Ser. 98, 263-274, 1993.

De Troch, M., Houthoofd, L., Chepurnov, V., and Vanreusel, A.: Does sediment grain size affect diatom grazing by harpacticoid copepods?, Mar. Environ. Res., 61, 265-277, 2006.

De Troch, M., Grego, M., Chepurnov, V. A., and Vincx, M.: A food patch size, food concentration and grazing efficiency of the harpacticoid Paramphiascella fulvofasciata (Crustacea, Copepoda), J. Exp. Mar. Biol. Ecol., 343, 210-216, 2007.

De Troch, M., Boeckx, P., Cnudde, C., Van Gansbeke, D., Vanreusel, A., Vincx, M., and Caramujo, M. J.: Bioconversion of fatty acids at the basis of marine food webs: insights from a compound-specific stable isotope analysis, Mar. Ecol.-Prog. Ser., 465, 53-67, 2012.

Diaz, R. J.: Overview of hypoxia around the world, J. Environ. Qual. 30, 275-281, 2001.

Diaz, R. J. and Rosenberg, R.: Spreading dead zones and consequences for marine ecosystems, Science, 321, 926-929, 2008.

Druon, J. N., Schrimpf, W., Dobricic, S., and Stips, A.: Comparative assessment of large-scale marine eutrophication: North Sea area and Adriatic Sea as case studies, Mar. Ecol.-Prog. Ser., 272, 123, 2004.

Eder, K.: Gas chromatographic analysis of fatty acid methyl esters, J. Chromatogr., 671, 113-131, 1995.

Elmgren, R.: Structure and dynamics of Baltic benthos communities, with particular reference to the relationship between macro and meiofauna, Kieler Meeresforsch. Sonderh., 4, 1-22, 1978.

Giere, O. (Ed): Meiobenthology: the Microscopic Motile Fauna of Aquatic Sediments, 2nd. Rev., Springer, 527 pp., 2009.

Gray, J. S., Wu, R. S. S., and Or, Y. Y.: Effects of hypoxia and organic enrichment on the coastal marine environment, Mar. Ecol.Prog. Ser., 238, 249-279, 2002.

Grego, M., De Troch, M., Cermelj, B., Forte, J., Berden-Zrimec, M., and Malej, A.: Impact of fish farming on meiofauna: a casestudy from the Bay of Piran (Slovenia), Mar. Pollut. Bull., 58, 1178-1186, 2009.

Grego, M., Stachowitsch, M., De Troch, M., and Riedel, B.: CellTracker Green labelling vs. Rose Bengal staining: CTG wins by points in distinguishing living from dead anoxia-impacted copepods and nematodes, Biogeosciences Discuss., 10, 2857-2887, doi:10.5194/bgd-10-2857-2013, 2013a.

Grego, M., Stachowitsch, M., De Troch, M., and Riedel, B.: Meiofauna winners and losers of coastal hypoxia: case study harpacticoid copepods, Biogeosciences, in preparation, 2013b.

Guillard, R. L.: Culture of phytoplankton for feeding marine invertebrates, in: Culture of marine invertebrate animals, edited by: Smith, W. L. and Chandley, M. H., Plenum Press, New York, 29-60, 1975.

Heip, C., Vincx, M., and Vranken, G.: The ecology of marine nematodes. Oceanogr, Mar. Biol. Annu. Rev. 23, 399-489, 1985.

Hicks G. R. F. and Coull, B. C.: The ecology of marine meiobenthic harpacticoid copepods. Oceanogr, Mar. Biol. Annu. Rev., 21, 380-389, 1983.

Hill M. O.: Diversity and evenness: a unifying notation and its consequences. Ecology, 54, 427-431, 1973.

Justin, S. H. F. W. and Armstrong, W.: Oxygen transport in the salt marsh genus Puccinellia with particular reference to the diffusive resistance of the root-shoot junction and the use of paraffin oil 
as a diffusive barrier in plant studies, J. Exp. Bot., 34, 980-986, 1983.

Kelly, J. R. and Scheibling, R. E.: Fatty acids as dietary tracers in benthic food webs, Mar. Ecol.-Prog. Ser., 446, 1-22, 2012.

Kennedy, A. D. and Jacoby, C. A.: Biological indicators of marine environmental health: Meiofauna - A neglected benthic component?, Environ. Monit. Assess., 54, 47-68, 1999.

Lang, K.: Monographie der Harpacticiden, Lund, Sweden, 1682 pp., 1948.

Lang, K.: Copepoda Harpacticoida from the Californian Pacific Coast. Kungliga Svenska Vetenskapsakademiens Handlingar, 10, 1-560, 1965.

Langlet, D., Baal, C., Geslin, E., Metzger, E., Zuschin, M., Riedel, B., Stachowitsch, M., and Jorissen, F. J.: Foraminiferal specific responses to experimentally induced anoxia in the Adriatic Sea, Biogeosciences, in press, 2013.

Kiørboe, T., Mohlenberg, F., and Hamburger, K.: Bioenergetics of the planktonic copepod Acartia tonsa: relation between feeding, egg production and respiration, and composition of specific dynamic action, Mar. Ecol.-Prog. Ser., 26, 85-97, 1985.

Masoro, E. J.: Dietary restriction-induced life extension: a broadly based biological phenomenon, Biogerontology, 7, 153-155, 2006.

Middelburg, J. J., Barranguet, C., Boschker, H. T. S., Herman, P. T., Moens, T., and Heip, C. H. R.: The fate of intertidal microphytobenthos carbon: an in situ ${ }^{13} \mathrm{C}$-labeling study, Limnol. Oceanogr., 45, 1224-1234, 2000.

Modig, H. and Ólafsson, E.: Responses of Baltic benthic invertebrates to hypoxic events, J. Exp. Mar. Biol. Ecol., 229, 133-148, 1998.

Monaghan, P., Metcalfe, N. B., and Torres, R.: Oxidative stress as a mediator of life history trade-offs: Mechanisms, measurements and interpretation, Ecol. Lett., 12, 75-92, 2009.

Moodley, L., v. d. Zwaan, G. J., Herman, P. M. J., Kempers, L., and van Breugel, P.: Differential response of benthic meiofauna to anoxia with special reference to Foraminifera (Protista: Sarcodina), Mar. Ecol.-Prog. Ser., 158, 151-163, 1997.

Moodley, L., Chen, G., Heip, C. H. R., and Vincx, M.: Vertical distribution of meiofauna in sediments from contrasting sites in the Adriatic Sea: clues to the role of abiotic versus biotic control, Ophelia, 53, 203-212, 2000.

Occhipinti-Ambrogi, A., Favruzzo, M., and Savini, D.: Multiannual variations of macrobenthos along the Emilia-Romagna coast (Northern Adriatic), PSZN Mar. Ecol., 23, 307-319, 2002.

Ott, J. A.: Adaptive strategies at the ecosystem level: examples from two benthic marine systems, P. S. Z. N. I, Mar. Ecol. 2, 113-158, 1981.

Rabalais, N. N., Turner, R. E., and Wiseman Jr., W. J.: Gulf of Mexico Hypoxia, a.k.a. "The Dead Zone”, Ann. Rev. Ecol. Syst., 33, 235-263, 2002.

Rabalais, N. N., Díaz, R. J., Levin, L. A., Turner, R. E., Gilbert, D., and Zhang, J.: Dynamics and distribution of natural and humancaused hypoxia, Biogeosciences, 7, 585-619, doi:10.5194/bg-7585-2010, 2010.

Riedel, B., Zuschin, M., and Stachowitsch, M.: Tolerance of benthic macrofauna to hypoxia and anoxia in shallow coastal seas: a realistic scenario, Mar. Ecol.-Prog. Ser., 458, 39-52, 2012.

Riedel, B., Pados, T., Pretterebner, K., Schiemer, L., Steckbauer, A., Haselmair, A., Zuschin, M., and Stachowitsch, M.: Effect of hypoxia and anoxia on invertebrate behaviour: ecological perspectives from species to community level, Biogeosciences, in preparation, 2013.

Sedlacek, C. and Marcus, N. H.: Egg production of the copepod Acartia tonsa: The influence of hypoxia and food concentration, J. Exp. Mar. Biol. Ecol., 318, 183-190, 2005.

Souza, M., Modenutti, B. E., Carrillo, P., Villar-Argaiz, M., MedinaSanchez, J. M., Bullejos, F., and Balseiro, E. G.: Stoichiometric dietary constraints influence the response of copepods to ultraviolet radiation-induced oxidative stress, Limnol. Oceanogr., 55, 1024-1032, 2010.

Stachowitsch, M.: Mass mortality in the Gulf of Trieste: the course of community destruction, PSZNI Mar. Ecol., 5, 243-264, 1984.

Stachowitsch, M., Riedel, B., Zuschin, M., and Machan, R.: Oxygen depletion and benthic mortalities: the first in situ experimental approach to documenting an elusive phenomenon, Limnol. Oceanogr.-Meth., 5, 344-352, 2007.

Stefanon, A. and Boldrin, A.: The oxygen crisis of the Northern Adriatic Sea waters in late fall 1977 and its effects on benthic communities, in: Proceedings of 6th International Science Symposium World Underwater Federation (CMAS), edited by: Blanchard, J., Mair, J., and Morrison, I., National Environmental Research Council, Edinburgh, 167-175, 1982.

Travizi A.: Effect of anoxic stress on density and distribution of sediment meiofauna, Period. Biol., 102, 207-215, 2000.

UNEP: United Nations Environment Programme: GEO Year Book 2003, GEO Section/UNEP, Nairobi, 2004.

Van Colen C., Montserrat, F., Verbist, K., Vincx, M., Steyaert, M. Vanaverbeke, J., Herman, P. M. J., Degraer, S., and Ysebaert T.: Tidal flat nematode responses to hypoxia and subsequent macrofauna-mediated alternations of sediment properties, Mar. Ecol.-Prog. Ser., 381, 189-197, 2009.

Van Colen, C., Rossi, F., Montserrat, F., Andersson, M. G. I., Gribsholt, B., Herman, P. M. J., Degraer, S., Vincx, M., Ysebaert, T., and Middelburg, J.: Organism-Sediment Interactions Govern Post-Hypoxia Recovery of Ecosystem Functioning, PLoS ONE, 7, e49795, doi:10.1371/journal.pone.0049795, 2012.

Vincx, M.: Meiofauna in marine and freshwater sediments, in: Methods for the examination of organismal diversity in soils and sediments, edited by: Hall, G. S., 187-195, 1996.

Vopel, K., Dehmlow, J., and Arlt, G.: Vertical distribution of Cletocamptus confluens (Copepoda, Harpacticoida) in relation to oxygen and sulphide microprofiles of a brackish water sulphuretum, Mar. Ecol.-Prog. Ser., 141, 129-137, 1996.

Wetzel, M. A., Fleeger, J. W., and Powers, S. P.: Effects of hypoxia and anoxia on meiofauna: A review with new data from the Gulf of Mexico, in: Coastal hypoxia: consequences for living resources and ecosystems, edited by: Rabalais, N. N. and Turner, R. E., Coast. Estuar. Stud., 58, American Geophysical Union, Whasington DC, 165-184, 2001.

Wetzel, M. A., Weber, A., and Giere, O.: Re-colonization of anoxic/sulfidic sediments by marine nematodes after experimental removal of macroalgal cover, Mar. Biol., 141, 679-689, 2002.

Widdows, J., Newell, R. I. E., and Mann, R.: Effects of hypoxia and anoxia on survival, energy metabolism, and feeding of oyster larvae (Crassostrea virginica, Gmelin), Biol. Bull., 177, 154-166, 1989.

Wright, S. W. and Jeffrey, S. W.: High-resolution HPLC system for chlorophylls and carotenoids of marine phytoplankton, in: Phyto- 
plankton pigments in oceanography: guidelines to modern methods, edited by: Jeffrey, S. W., Mantoura, R. F. C., and Wright, S. W., Monogr. Oceanogr. Method., 10, 327-341, 1997.

Wu, R. S.: Hypoxia: from molecular responses to ecosystem responses, Mar. Pollut. Bull., 45, 35-45, 2002.
Zhou, J.: Impacts of mariculture practices on the temporal distribution of macrobenthos in Sandu Bay, South China, Chin. J. Oceanol. Limn., 30, 3880-396, 2012. 